УДК 616.27-002-036:616.155.392:612.017

DOI 10.11603/1811-2471.2018.v0.i1.8610

\title{
ОСОБЛИВОСТІ ПЕРЕБІГУ ПНЕВМОНІЙ ПРИ ОНКОЛОГІЧНИХ ЗАХВОРЮВАННЯХ КРОВІ
}

\author{
๑А. О. Боб, А. І. Хоміцька, О. О. Чукур, Л. В. Радецька, І. П. Савченко, \\ Л. П. Боднар, О. С. Квасніцька, В. Є. Городецький
}

ДВНЗ «Тернопільський державний медичний університет імені І. Я. Горбачевського мОз України»

РЕЗЮМЕ. Найчастішими інфекційними ускладненнями при лейкозі $\epsilon$ пневмонії, які досить часто стають основною причиною смерті хворих.

Мета роботи - визначення етіологічного чинника пневмоній у хворих з тяжкими порушеннями імунітету на фоні онкологічних захворювань крові.

Матеріал і методи. Обстежено 124 хворих на пневмонію з онкологічними захворюваннями крові. Проводили мікробіологічне дослідження мокротиння та рідини бронхоальвеолярного лаважу шляхом вивчення нативних мазків із визначенням основних морфологічних типів збудників.

Результати. У результаті мікробіологічних досліджень ймовірні бактеріальні збудники захворювання було виявлено в 69,4 \% випадків. Серед 89 позитивних результатів мікробіологічних досліджень провідними були грамнегативні мікроорганізми, що становили 68,6 \%. Грампозитивні мікроорганізми були визначені в 26,7 \% досліджень. Асоціації патогенних мікроогранізмів визначені у 53,3 \% хворих групи дослідження: 3 грибковою флорою - у 52,4\%; асоціації бактерій - у 26,7\%.

Висновки. Проблема визначення етіологічного чинника пневмонії у пацієнтів з онкологічними захворюваннями крові $є$ актуальною та потребує подальших досліджень для оптимізації лікування та прогнозування перебігу пневмонії.

КЛючОВІ СлОВА: пневмонія; онкологічні захворювання крові; інфекційні збудники.

Вступ. Інфекційні ускладнення при лейкозі спостерігають досить часто, вони є однією з основних причин смерті хворих. Серед тяжких інфекцій перше місце за частотою займають пневмонії. За даними деяких дослідників, їх частота при гострих лейкозах становить $79 \%$, при хронічному мієлолейкозі - $41 \%$, у хворих на хронічний лімфолейкоз - 48 \% [1]. Хворі з порушеннями імунітету на фоні онкологічних захворювань крові мають вищий ризик розвитку пневмонії, ніж у середньому в популяції, у зв'язку із наявністю у них таких факторів ризику: анемія, нейтропенія, гіпогаммаглобулінемія, хіміотерапія, глюкокортикостероїдна терапія, стан після трансплантації органів $[2,4]$. Застосування цитостатиків призводить до зменшення кількості нейтрофілів, що порушує їх захисні функції [3]. Глюкокортикостероїдні препарати погіршують фагоцитарні та міграційні функції нейтрофілів, що проявляється якісними дефектами процесів хемотаксису, фагоцитозу та реалізації бактерицидних властивостей [5]. Хіміопрепарати, що $є$ досить токсичними, додатково ушкоджують Т- і В-лімфоцити, що також знижує їх функціональну активність та проявляється в неспроможності викликати лізис бактерій та нейтралізувати їхні токсини.

Мета роботи - визначити особливості перебігу пневмоній у хворих з тяжкими порушеннями імунітету на фоні онкологічних захворювань крові.
Матеріал і методи дослідження. Досліджено 124 хворих на пневмонію на фоні онкологічних захворювань крові, які отримували програмне лікування на базі гематологічного відділення К3 «Тернопільська університетська лікарня» протягом 2016-2017 рр. Вік хворих становив від 32 до 76 років. Серед досліджуваних було 52 жінки і 72 чоловіки. Діагноз онкологічних захворювань крові було верифіковано відповідно до загальноприйнях клінічних та морфологічних критеріїв, що закріплені Наказом МО3 України № 554 від 17.09.2007 р. «Про затвердження протоколів надання медичної допомоги за спеціальністю «Онкологія» із доповненнями згідно з Наказом МОЗ України № 645 від 30.07.2010р. Діагноз пневмонії було верифіковано відповідно до Наказу МО3 України №128 від 19.03.2007 р. Матеріалом для ідентифікації збудників пневмонії були: мокротиння, отримане методом індукції мокротиння, та рідина бронхоальвеолярного лаважу (БАЛ), отримана при фібробронхоскопії (ФБС). Мікробіологічне дослідження мокротиння і БАЛ проводили шляхом вивчення нативних мазків із визначенням основних морфологічних типів. Проведення якісного мікробіологічного дослідження проводили поетапно на щільних диференціально-поживних середовищах. Статистична обробка отриманих результатів виконана за допомогою стандартного пакета функцій “MS Excel”. 


\section{Огляди літератури, оригінальні дослідження, погляд на проблему}

Результати й обговорення. Розподіл у групі дослідження за нозологічними формами онкологічних захворювань був таким: у 28 (22,6 \%) хворих групи дослідження пневмонія виникла на фоні гострого лімфобластного лейкозу; у 6 (4,8\%) хворих - на фоні гострого промієлоцитарного лейкозу; у 36 (29\%) хворих - на фоні гострого мієлобластного лейкозу; у 14 (11,3 \%) хворих - на фоні хронічного мієлолейкозу; у 32 (25,8 \%) хворих - на фоні хронічного лімфолейкозу; у 8 (6,5\%) хворих - на фоні інших онкологічних захворювань крові.

У 88 (70,9 \%) хворих було проведено дослідження мокротиння методом індукованого мокротиння, у 36 (29,1 \%) хворих, у зв'язку з відсутністю мокротиння, було проведено дослідження рідини БАЛ, отриманої при ФБС. Всього в групі дослідження патологічні мікроорганізми в діагностично значущій концентрації були визначені у 86 хворих, що становило 69,4\%.

За результатами мікробіологічних досліджень хворих на пневмонію на фоні онкологічних захворювань крові грамнегативні мікроорганізми були визначені у 59 хворих, що становило 68,6 \%. Грампозитивні мікроорганізми були визначені у 23 хворих, що становило 26,7 \%. У 51 (59,3 \%) хворого групи дослідження визначені асоціації збудників. Серед них поєднання з грибковими патогенами було визначено у $45(52,4 \%)$ хворих, бактеріальні асоціації визначені у 23 (26,7 \%) хворих. Основними представниками грибкової флори в асоціаціях були представники роду Candida spp.; представники роду Aspergillus spp. були визначені у 7 (8,2 \%) хворих. Типові збудники пневмонії, такі як S. рпеиmoniae, $H$. influenzae, K. pneumoniae, в групі дослідження були визначені у 17 (19,8 \%) хворих. Збуд-

\section{ЛІТЕРАТУРА}

1. Авдеев С. Н. Применение метода индуцированной мокроты для оценки интенсивности воспаления дыхательных путей / С. Н. Авдеев, Э. Х. Анаев, А. Г. Чучалин // Пульмонология. - 2010. - № 4. - С. 81-87.

2. Дзюблик Я. О. Клінічні аспекти антибіотикорезистентності збудників негоспітальних інфекцій дихальних шляхів / О. Я. Дзюблик // Укр. пульмонол. журнал. 2010. - № 3. - С. 53-56.

3. Негоспітальна пневмонія у дорослих осіб: етіологія, патогенез, класифікація, діагностика, антибіотикобактеріальна терапія (Проект клінічних настанов) / ники пневмонії, що є провідними серед патогенів нозокоміальної інфекції, такі як $P$. aeroginosa, S. pyogenus, Staphilococcus aureus, визначали у 26 (30,2 \%) хворих. Представники родини Enterobacteriaceae (E.coli, Proteus vulgaris, Enterobacter spp.) визначені у 19 (22,1 \%) хворих. Грамнегативні неферментуючі бактерії у групі дослідження виявлені у 7 (8,1%) хворих. Частіше ці збудники визначали в асоціаціях з іншими бактеріальними патогенами. Значну частку (12,9\%) типових для хворих з порушеннями імунітету збудників пневмонії в групі дослідження склали Serratia marcescens, Streptococcus viridans, Shewanella putrefaciens, Acinetobacter sp. Незважаючи на використання сучасних методів дослідження, практично у 30,6 \% пневмоній у цієї категорії хворих залишилися етіологічно невизначеними.

Висновки. 1. За результатами мікробіологічних досліджень 124 хворих на пневмонію на фоні онкологічних захворювань крові ймовірні бактеріальні збудники захворювання було визначено в 69,4 \% випадків.

2. Серед 89 позитивних результатів мікробіологічних досліджень провідними були грамнегативні мікроорганізми, що становили 68,6 \%. Грампозитивні мікроорганізми були визначені в 26,7 \% досліджень. Асоціації патогенних мікроогранізмів визначені у 53,3\% хворих групи дослідження: 3 грибковою флорою - у 52,4 \%; асоціації бактерій у $26,7 \%$.

Перспективи подальших досліджень. Проблеми визначення етіологічного чинника пневмонії у хворих з онкологічними захворюваннями крові $\epsilon$ актуальними та потребують подальших досліджень для оптимізації лікування та прогнозування перебігу пневмонії.

Ю. І. Фещенко, О. А. Голубовська, К. А. Гончаров, О. Я. Дзюблик // Укр. пульмонол. журнал. - 2012. - № 4. С. 5-17.

4. Перцева Т. О. Пневмонії у хворих на фоні онкологічних захворювань крові / Т. О. Перцева, І. С. Борисова // Клінічна медицина. - 2014. - № 14. Т. XIX/1. C. 45-49.

5. Shorr A. F. Quality pneumonia care: distinguishing community-acquired from health careassociated pneumonia / A. F. Shorr, R. C. Owens // Am. J. Health Syst. Pharm. 2009. - Vol.66, No. 12, Suppl. 4. - P. 8-14.

sity of respiratory tract inflammation]. Pulmonologiya Pulmonology, 4, 81-87 [in Russian].

2. Dzyublik, Ya.O. (2010). Klinichni aspekty antybiotykoresystentnosti zbudnykiv nehospitalnykh infektsii dy- 
Огляди літератури, оригінальні дослідження, погляд на проблему

khalnykh shliakhiv [Clinical aspects of resistence of antimicrobial agents of community acquired respiratory tract infections]. Ukrainskyi pulmonolohichnyi zhurnal Ukrainian Pulmonolgy Journal, 3, 53-56 [in Ukrainian].

3. Feshchenko, Yu.I., Holubovska, O.A., Honcharov, K.A., \& Dzublyk, O.Ya. (2012). Nehospitalna pnevmoniia u doroslykh osib: etiolohiia, patohenez, klasyfikatsiia, diahnostyka, antybiotybakterialna terapiia (Proekt klinichnykh nastanov) [Non-hospital pneumonia in adults: etiology, pathogenesis, classification, diagnosis, antibiotic bacterial therapy (Project of clinical guidelines)]. Ukrainskyi pulmo-

nolohichnyi zhurnal - Ukrainian Pulmonology Journal, 4, 5-17 [in Ukrainian].

4. Pertseva, T.O., \& Borisova, I.S. (2014). Pnevmonii u khvorykh na foni onkolohichnykh zakhvoriuvan krovi [Pneumonia in patients on the background of oncological diseases of blood]. Klinichna medytsyna-Clinical Medicine, $X I X / 1(14), 45-49$.

5. Shorr, A.F., \& Owens, R.C. (2009). Quality pneumonia care: distinguishing community-acquired from health careassociated pneumonia. Am. J. Health Syst. Pharm., 66 (12), 4, 8-14.

\title{
ОСОБЕННОСТИ ТЕЧЕНИЯ ПНЕВМОНИЙ ПРИ ОНКОЛОГИЧЕСКИХ ЗАБОЛЕВАНИЯХ КРОВИ
}

๑А. О. Боб, А. И. Хомицкая, О. О. Чукур, Л. В. Радецкая, И. П. Савченко, Л. П. Боднар, О. С. Квасницкая, В. Е. Городецкий

ГВУз «Тернопольский государственный медицинский университет имени И. Я. Горбачевского МЗ Украины»

РЕЗЮМЕ. Частыми инфекционными осложнениями при лейкозе являются пневмонии, достаточно часто они стают основной причиной смерти больных.

Целью работы было определение этиологического фактора пневмонии у больныхстяжелыми нарушениями иммунитета на фоне онкологических заболеваний крови.

Материал и методы. Обследовано 124 больных пневмонией с онкологическим заболеванием крови. Проводили микробиологическое исследование мокроты и жидкости бронхоальвеолярного лаважа путем изучения нативных мазков с определением основных морфологических типов возбудителей.

Результаты исследований. По результатам микробиологических исследований вероятные бактериальные возбудители заболевания были определены в 69,4 \% случаев. Среди 89 положительных результатов микробиологических исследований ведущими были грамотрицательные микроорганизмы, которые составили 68,6 \%. Грамположительные микроорганизмы были определены в 26,7 \% исследований. Ассоциации патогенных микроогранизмов определены у 53,3 \% больных: с грибковой флорой - у 52,4 \%; ассоциации бактерий - у 26,7 \%.

Выводы. Проблемы определения этиологического фактора пневмонии у больных онкологическими заболеваниями крови актуальны и требуют дальнейших исследований для оптимизации лечения и прогнозирования течения пневмонии.

КЛЮчЕВЫЕ СЛОВА: пневмония; онкологические заболевания крови; инфекционные возбудители.

\section{FEATURES OF PNEUMONIA COURSE IN ONCOLOGICAL BLOOD DISEASES}

\author{
๑A. O. Bob, A. I. Khomitska, O. O. Chukur, L. V. Radetska, I. P. Savchenko,
} L. P. Bodnar, O. S. Kvasnitska, V. Y. Horodetskyi

\section{Horbachevsky Ternopil State Medical University}

SUMMARY. The most common infectious complications of leukemia are pneumonia, which is often the main cause of the death of these patients.

The aim of the work was to determine the etiological factor of pneumonia in patients with severe immune disorders on the background of oncological diseases of the blood.

Material and Methods. 124 patients with pneumonia and oncological diseases of the blood were examined. A microbiological study of sputum and fluid of bronchoalveolar lavage was determined by studying native smears with the definition of the main morphological types of pathogens.

Results. According to the results of microbiological studies, probable bacterial pathogens of the disease were identified in $69.4 \%$ of cases. Among the 89 positive results of microbiological research, gram-negative microorganisms were the leading, accounting for $68.6 \%$. Gram-positive microorganisms were identified in $26.7 \%$ of the studies. Associations of pathogenic microgranisms have been identified in $53.3 \%$ of patients in the study group: with fungal flora $-52.4 \%$; the association of bacteria $-26.7 \%$.

KEY WORDS: pneumonia; oncological diseases of the blood; infectious pathogens.

Отримано 21.02.2018 